\title{
Plant-Parasitic Nematodes Are Potential Pathogens of Miscanthus $\times$ giganteus and Panicum virgatum Used for Biofuels
}

Tesfamariam Mekete and Kimberly Reynolds, Energy Biosciences Institute, Horacio D. Lopez-Nicora, Department of Crop Sciences, and Michael E. Gray and Terry L. Niblack, Energy Biosciences Institute and Department of Crop Sciences University of Illinois, Urbana, 61801

\begin{abstract}
Mekete, T., Reynolds, K., Lopez-Nicora, H. D., Gray, M. E., and Niblack, T. L. 2011. Plant-parasitic nematodes are potential pathogens of Miscanthus $\times$ giganteus and Panicum virgatum used for biofuels. Plant Dis. 95:413-418.

A survey of Miscanthus $\times$ giganteus and switchgrass plots throughout the midwestern and southeastern United States was conducted to determine the occurrence and distribution of plant-parasitic nematodes associated with these biofuel crops. During 2008, rhizosphere soil samples were collected from 24 Miscanthus $\times$ giganteus and 38 switchgrass plots in South Dakota, Iowa, and Illinois. Additional samples were collected from 11 Miscanthus $\times$ giganteus and 10 switchgrass plots in Illinois, Kentucky, Georgia, and Tennessee the following year. The 11 dominant genera recovered from the samples were Pratylenchus, Helicotylenchus, Xiphinema, Longidorus, Heterodera, Hoplolaimus, Tylenchorhynchus, Criconemella, Paratrichodorus, Hemicriconemoides, and Paratylenchus. Populations of Helicotylenchus, Xiphinema, and Pratylenchus were common and recorded in 90.5, 83.8, and $91.9 \%$ of the soil samples from Miscanthus $\times$ giganteus, respectively, and in $91.6,75$, and $83.3 \%$ of the soil samples from switchgrass, respectively. Prominence value $(\mathrm{PV})(\mathrm{PV}=$ population density $\times$ $\checkmark$ frequency of occurrence/10) was calculated for the nematodes identi-

fied. Helicotylenchus had the highest PV $(\mathrm{PV}=384)$ and was followed by Xiphinema $(\mathrm{PV}=152)$ and Pratylenchus $(\mathrm{PV}=72)$. Several of the nematode species associated with the two biofuels crops were plant parasites. Of these, Pratylenchus penetrans, P. scribneri, P. crenatus, Helicotylenchus pseudorobustus, Hoplolaimus galeatus, $X$. americanum, and $X$. rivesi are potentially the most damaging pests to Miscanthus $\times$ giganteus and switchgrass. Due to a lack of information, the damaging population thresholds of plant-parasitic nematodes to Miscanthus $\times$ giganteus and switchgrass are currently unknown. However, damage threshold value ranges have been reported for other monocotyledon hosts. If these damage threshold value ranges are any indication of the population densities required to impact Miscanthus $\times$ giganteus and switchgrass, then every state surveyed has potential for yield losses due to plant-parasitic nematodes. Specifically, Helicotylenchus, Xiphinema, Pratylenchus, Hoplolaimus, Tylenchorhynchus, Criconemella, and Longidorus spp. were all found to have population densities within or above the threshold value ranges reported for other monocotyledon hosts.
\end{abstract}

Interest in the use of perennial grasses as energy crops in the United States and Europe has been increasing since the mid-1980s. The characteristics that make perennial grasses attractive for biomass production are their high yield potential, high contents of lignin and cellulose, and generally anticipated positive environmental impact. Two of the top energy-yielding cellulosic-ethanol feedstock plants are the perennial grasses Miscanthus $\times$ giganteus and switchgrass (Panicum virgatum L.) $(19,45)$. Miscanthus $\times$ giganteus, a hybrid of Miscanthus sinensis and M. sacchariflorus, is $\mathrm{a} \mathrm{C}_{4}$ grass native to Asia. It has a high yield potential (19) and efficiently converts radiation to biomass (4). Switchgrass is a native prairie species adapted to most areas of the United States. It has been used for livestock feed, for wildlife habitat, and in soil conservation programs $(32,45)$. These perennial grasses produce large quantities of biomass, require relatively little fertilizer and water, and can be used for fuel either by burning or in ethanol generation $(45,46)$.

Research on the production of Miscanthus $\times$ giganteus and switchgrass as biofuel crops has mainly involved breeding for increased biomass yield and developing practices for nitrogen fertilization, weed control, and harvest. Few studies, however, have determined the impact of pests and diseases on Miscanthus $\times$ giganteus and switchgrass. Diseases and pests have the potential to cause significant constraints on plant growth and development, which puts the crops at risk for reductions in biomass yield and quality. Of the many pests and diseases, plant-parasitic nematodes

Corresponding author: T. Mekete, E-mail: tmekete@illinois.edu

Accepted for publication 6 October 2010.

doi:10.1094/PDIS-05-10-0335

(C) 2011 The American Phytopathological Society could be of great economic importance because they can directly reduce plant biomass and predispose plants to attack by other soilborne pathogens $(49,53)$.

Many species of plant-parasitic nematodes have been found associated with economically important monocot fiber and food crops throughout the world (28). Several of these reported in North America have been associated with monocotyledon hosts. including prairie grass, switchgrass, turf grass, and corn $(6,11,13,24$, 42,56). The following genera of nematodes have been detected in the tallgrass prairie of the United States: Filenchus, Helicotylenchus, Xiphinema, Aporcelaimellus, Dorylaimellus, Mesocriconema, Basiria, Plectus, Coslenchus, and Pungentus (51). Twentyone species of plant-parasitic nematodes belonging to the families Aphelenchoidea, Tylenchinae, Psilenchinae, and Dorylaimoidea were reported from the Kalsow Prairie in Iowa (41). In a survey of nematodes associated with established switchgrass stands in the south-central United States, Cassida et al. (6) detected Xiphinema americanum, Tylenchorhynchus spp., Paratrichodorus minor, Criconemella ornata, Hoplolaimus magnistylus, Pratylenchus zeae, Helicotylenchus spp., Meloidogyne spp., and Paratylenchus spp. These authors noted variation in the population density of plantparasitic nematodes among switchgrass genotypes and, in some cases, nematode numbers were negatively correlated with stand persistence or dry matter yield (6). In a greenhouse study in Georgia, Johnson (23) reported that species of Criconemella, Tylenchorhynchus, and Belonolaimus readily reproduced on and reduced the biomass of six varieties of bermudagrass. In a similar study, Ingham and Detling (22) reported that nematodes in the orders Tylenchida and Dorylaimida consumed up to $16.4 \%$ of annual net root production of western wheatgrass and $8.9 \%$ of little bluestem grass in South Dakota. Sikora et al. (47) reported that a root-knot nematode, Meloidogyne naasi, alone or in combination with $P$. penetrans or Tylenchorhynchus agri, reduced the root growth and biomass of bentgrass in a greenhouse study. In contrast, Kokalis- 
Burelle (25) reported that switchgrass, when planted in rotation with peanut in Alabama, did not support root-knot nematodes but did support a large number of nonparasitic nematodes.

Few reports have documented the plant-parasitic nematodes associated with Miscanthus sinensis, a parent material of Miscanthus $\times$ giganteus. Root and rhizosphere soil samples taken in Japan included the nematodes Nothocriconemella miscanthi (35), Verutus mesoangustus (36), and Radopholus sanoi (37). M. sinensis has been reported to be a susceptible host of Meloidogyne hapla in Connecticut (27). Even fewer reports are available concerning nematodes associated with Miscanthus $\times$ giganteus. Mekete et al. (34) found $X$. americanum, $X$. rivesi, and Longidorus breviannulatus associated with Miscanthus $\times$ giganteus in Illinois. L. breviannulatus, in particular, was associated with severe damage to the fibrous root system, including stunting and necrosis (34).

To help assess the importance of plant-parasitic nematodes in biofuels crops, a survey was conducted with the objective of providing preliminary information on the distribution, presence, and abundance of species associated with Miscanthus $\times$ giganteus and switchgrass.

\section{Materials and Methods}

Soil samples were collected from 24 Miscanthus $\times$ giganteus and 38 switchgrass managed plots in the states of Illinois, Iowa, and South Dakota during the 2008 growing season (Table 1). Additional soil samples were collected from 11 Miscanthus $\times$ giganteus and 10 switchgrass plots in the states of Illinois, Iowa, Kentucky, Tennessee, and Georgia during the 2009 growing season (Table 1). Samples were collected once per site in June through August of both years. All plots in Illinois, Iowa, and South Dakota were planted in 2002, 2005 and 2007, respectively, whereas plots in Kentucky, Tennessee, and Georgia were planted in 2008. All sampling sites, except Dudely Smith, IL, are university experimental plots. All plot sizes range from 100 to $200 \mathrm{~m}^{2}$.

The elevation, latitude, and longitude for each sampling site were recorded using the Global Positioning System (GPS) (Garmin GPSMAP 60CSx; Garmin International Inc., KS). Geographical coordinates recorded for each farm were mapped with ArcView 3.2 (ESRI, Redlands, CA) (Fig. 1). Soil type was assigned using the GPS coordinates and the Natural Resource Conservation Service's
(NRCS) internet soil survey application (NRCS, Washington, DC.) (Table 1).

In each plot, 20 to 25 soil cores were collected near the rhizosphere of Miscanthus $\times$ giganteus and switchgrass plants at a depth of 20 to $30 \mathrm{~cm}$. The cores were combined at the time of collection to form one composite soil sample per plot and placed in a plastic sample bag. All samples were kept at $4^{\circ} \mathrm{C}$ until processed, and nematodes were extracted within a 2-week period.

Composite samples were mixed thoroughly and one $100-\mathrm{cm}^{3}$ subsample was used for nematode extraction via wet sieving followed by a sugar flotation centrifugal method (20). Briefly, 100 $\mathrm{cm}^{3}$ of soil was immersed in a bucket containing 2 liters of water and gently hand stirred until all soil aggregates disintegrated. After $30 \mathrm{~s}$, the slurry was passed through nested 250-, 100-, and 25- $\mu \mathrm{m}$ pore sieves. This step was repeated until only sand and rocks remained in the bucket. Material on the $25-\mu \mathrm{m}$ sieve was retained and processed by a sugar flotation centrifugal method to recover the nematodes collected. Larger nematodes in the genera of Xiphinema, Longidorus, and Hoplolaimus retained on the 100- $\mu$ m sieve were collected and further processed using Baermann funnels that contained a single layer of cheesecloth (20). After $48 \mathrm{~h}$, about 25 to $40 \mathrm{ml}$ of water with nematodes was collected from the Baermann funnels. Nematodes were identified to the genus level with a dissecting microscope at $\times 40$ to 63 and enumerated as the number of

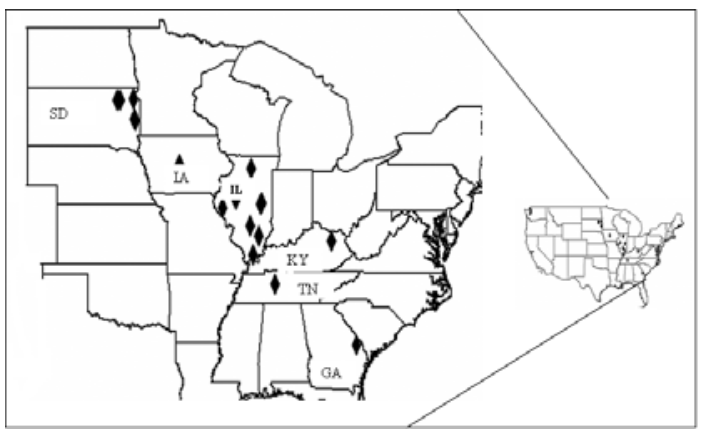

Fig. 1. Distribution and Global Positioning System location of sampling sites. SD, South Dakota; IA, lowa; IL, Illinois; KY, Kentucky; TN, Tennessee; GA, Georgia.

Table 1. Mean number of different plant-parasitic nematode genera extracted from 100- $\mathrm{cm}^{3}$ rhizosphere soil samples, collected from Miscanthus $\times$ giganteus and switchgrass plots in six midwestern and southeastern states in the United States ${ }^{\mathrm{a}}$

\begin{tabular}{|c|c|c|c|c|c|c|c|c|c|c|c|c|c|c|c|c|}
\hline \multirow[b]{2}{*}{ City, state } & \multirow[b]{2}{*}{ Year $^{c}$} & \multirow[b]{2}{*}{ No. ${ }^{d}$} & \multirow[b]{2}{*}{ Soil type $^{\mathrm{e}}$} & \multicolumn{2}{|c|}{$\begin{array}{l}\text { A Horizon } \\
(\text { range, \%) }\end{array}$} & \multicolumn{11}{|c|}{ Genera $^{b}$} \\
\hline & & & & Clay & Sand & Helic & Xip & Praty & Long & Heter & Нор & Tylen & Cric & Paratri & Hemi & Paraty \\
\hline Urbana, IL & Both & 4 & SCL & $20-35$ & $<15$ & $284(186)$ & $360(1,200)$ & $206(94)$ & $0(0)$ & $66(124)$ & $0(0)$ & $0(0)$ & $0(0)$ & $0(0)$ & $0(0)$ & $22(8)$ \\
\hline Savoy, IL & Both & 2 & SCL & $20-35$ & $<15$ & $102(138)$ & $312(108)$ & $66(162)$ & $0(0)$ & $12(72)$ & $0(0)$ & $0(0)$ & $54(26)$ & $0(0)$ & $0(0)$ & $78(132)$ \\
\hline Dixon Springs, IL & 2008 & 1 & Silt loam & $25-35$ & $2-10$ & $850(386)$ & $18(50)$ & $184(96)$ & $0(0)$ & $0(0)$ & $156(224)$ & $0(0)$ & $0(0)$ & $0(0)$ & $0(0)$ & $0(0)$ \\
\hline Dudley Smith, IL & 2008 & 1 & Silt loam & $20-27$ & $<7$ & $800(260)$ & $167(246)$ & $98(26)$ & $0(0)$ & $0(0)$ & $0(0)$ & $0(0)$ & $0(0)$ & $52(0)$ & $0(0)$ & $0(0)$ \\
\hline Fairfield, IL & 2008 & 1 & Silt loam & $20-27$ & $<15$ & $670(660)$ & $0(0)$ & $87(24)$ & $0(0)$ & $0(0)$ & $88(0)$ & $167(80)$ & $0(0)$ & $0(0)$ & $0(0)$ & $0(0)$ \\
\hline DeKalb, IL & 2008 & 1 & SCL & $25-30$ & $<10$ & 147 (248) & $80(25)$ & $90(34)$ & $0(0)$ & $18(24)$ & $0(0)$ & $0(0)$ & $0(0)$ & $0(16)$ & $0(0)$ & $0(0)$ \\
\hline Browntown, IL & 2008 & 1 & Silt loam & $25-30$ & 5-15 & $140(660)$ & $167(120)$ & $156(88)$ & $0(0)$ & $0(0)$ & $0(0)$ & $52(146)$ & $68(126)$ & $0(0)$ & $0(0)$ & $28(67)$ \\
\hline Havana, IL & 2008 & 1 & Sandy loam & $5-18$ & $50-80$ & $130(142)$ & $0(0)$ & $175(420)$ & $26(33)$ & $26(86)$ & 88 (146) & $24(38)$ & $160(340)$ & $0(0)$ & $0(0)$ & $12(58)$ \\
\hline Perry, IL & 2008 & 1 & Silt loam & $18-27$ & $<8$ & $0(0)$ & $130(660)$ & $0(0)$ & $0(0)$ & $220(48)$ & $0(0)$ & $125(32)$ & $0(0)$ & $0(0)$ & $0(0)$ & $134(220)$ \\
\hline Ames, IA & Both & 4 & Clay loam & $18-35$ & $18-45$ & $158(690)$ & $5(16)$ & 40 (112) & $0(0)$ & 384 (647) & $6(32)$ & $0(0)$ & $6(22)$ & $0(0)$ & $0(20)$ & $56(126)$ \\
\hline Brookings $1, \mathrm{SD}$ & 2008 & 2 & SCL & 27 & 17 & $-(380)$ & $-(0)$ & $-(28)$ & $-(0)$ & $-(68)$ & $-(0)$ & $-(286)$ & $-(0)$ & $-(0)$ & $-(0)$ & $-(96)$ \\
\hline Brookings 2, SD & 2008 & 1 & Clay loam & $28-35$ & $30-40$ & $-(87)$ & $-(0)$ & $-(0)$ & $-(0)$ & $-(46)$ & $-(0)$ & $-(127)$ & $-(0)$ & $-(0)$ & $-(0)$ & $-(132)$ \\
\hline Bristol 1, SD & 2008 & 3 & Clay loam & $35-45$ & 20 & $-(0)$ & $-(0)$ & $-(0)$ & $-(0)$ & $-(0)$ & $-(0)$ & $-(0)$ & $-(0)$ & $-(0)$ & $-(0)$ & $-(12)$ \\
\hline Bristol 2, SD & 2008 & 1 & Loam & $20-30$ & $>30$ & $-(22)$ & $-(0)$ & $-(0)$ & $-(0)$ & $-(0)$ & $-(0)$ & $-(0)$ & $-(0)$ & $-(0)$ & $-(0)$ & $-(36)$ \\
\hline Lexington, KY & 2009 & 2 & Silt loam & $15-20$ & $5-10$ & $40(320)$ & $0(0)$ & $67(53)$ & $0(0)$ & $0(0)$ & $0(0)$ & $0(0)$ & $0(0)$ & $0(0)$ & $0(0)$ & $0(0)$ \\
\hline Milan, TN & 2009 & 2 & Silt loam & $18-25$ & $<15$ & $-(480)$ & $-(0)$ & $-(10)$ & $-(0)$ & $-(4)$ & $-(0)$ & $-(0)$ & $-(35)$ & $-(0)$ & $-(0)$ & $-(0)$ \\
\hline Midville, GA & 2009 & 1 & Loamy sand & $1-10$ & $70-85$ & $96(132)$ & $0(26)$ & $27(73)$ & $5(0)$ & $0(0)$ & $0(0)$ & $187(58)$ & $0(0)$ & $0(0)$ & $0(0)$ & $0(0)$ \\
\hline
\end{tabular}

${ }^{\text {a }}$ Data presented here are averaged for 2008 and 2009 sampling periods.

${ }^{\mathrm{b}}$ Helicotylenchus (Helic), Xiphinema (Xip), Pratylenchus (Praty), Longidorus (Long), Heterodera (Heter), Hoplolaimus (Hop), Tylenchorhynchus (Tylen), Criconemella (Cric), Paratrichodorus (Paratri), Hemicriconemoides (Hemi), and Paratylenchus (Paraty). Counts in parentheses are mean numbers for Miscanthus $\times$ giganteus and switchgrass, respectively; 0 indicates zero count for the given nematode and - indicates no soil sample taken.

${ }^{\mathrm{c}}$ Sampling year; Both $=2008$ and 2009.

${ }^{\mathrm{d}}$ Number of sites sampled.

${ }^{\mathrm{e}} \mathrm{SCL}=$ silty clay loam. Data extracted from the United States Department of Agriculture, Natural Recourse Conservation Service (http:// websoilsurvey.nrcs.usda.gov/app/WebSoilSurvey.aspx) based on our survey Global Positioning System points. 
nematodes per $100 \mathrm{~cm}^{3}$ of soil. Frequency of occurrence and population density were used to calculate a prominence value. Prominence value $(\mathrm{PV})=$ population density $\times \sqrt{\text { frequency of occur- }}$ rence/10 (10).

Identification of plant-parasitic nematodes was based on morphological methods. Some genera of nematodes were not identified to the species level because of a limited number of adult females. Nematodes were killed in hot water at $65^{\circ} \mathrm{C}$ and fixed in a formalin acetic acid fixative (4:1) solution containing $10 \mathrm{ml}$ of formalin, $1 \mathrm{ml}$ of glacial acetic acid, $2 \mathrm{ml}$ of glycerol, and distilled water up to 100 $\mathrm{ml}(21)$. The nematode specimens were dehydrated using a glycerin method and mounted in pure glycerin on glass slides (20). Morphometric analyses of the nematode specimens were made using light microscopy and image-analyzing software (Zeiss Axion A1 imager version 4.0; New York). The species were identified with keys and descriptions by various authors $(1,5,7,9,14-18,26,34)$.

\section{Results}

Plant-parasitic nematodes were found in all of the samples tested. The 11 dominant genera recovered from the soil samples were Pratylenchus, Helicotylenchus, Xiphinema, Longidorus, Heterodera, Hoplolaimus, Tylenchorhynchus, Criconemella, Paratrichodorus, Hemicriconemoides, and Paratylenchus (Table 1). All of these genera contain one or more species of plant-parasitic

Table 2. Nematode damage threshold values, population density, and prominence values for the predominant nematode species associated with Miscanthus $\times$ giganteus $(M \times g)$ and switchgrass (Switch) plots in six midwestern and southeastern states in the United States in 2008 and 2009

\begin{tabular}{lcccc}
\hline & & & \multicolumn{2}{c}{ Prominence value $^{\mathbf{a}}$} \\
\cline { 4 - 5 } Nematode genus & Damage $^{\mathbf{b}}$ & Population $^{\mathbf{c}}$ & $\boldsymbol{M} \times \boldsymbol{g}$ & Switch \\
\hline Helicotylenchus & $300+$ & $0-850$ & 384 & 275 \\
Xiphinema & $50-100$ & $0-1,200$ & 131 & 152 \\
Pratylenchus & $50-100$ & $0-420$ & 70 & 72 \\
Hoplolaimus & $40-150$ & $0-224$ & 64 & 25 \\
Tylenchorhynchus & $150-300$ & $0-226$ & 24 & 32 \\
Criconemella & $300-600$ & $0-340$ & 8 & 20 \\
Longidorus & $5-25$ & $0-54$ & 3 & 2 \\
\hline
\end{tabular}

a Prominence value $=$ population density $\times \sqrt{ }$ frequency of occurrence $/ 10$.

${ }^{\mathrm{b}}$ Range (minimum-maximum) of damage threshold numbers per $100 \mathrm{~cm}^{3}$ of soil; guidelines used for monocotyledon hosts based on findings from the University of Illinois $(2,3)$.

${ }^{\mathrm{c}}$ Range (minimum-maximum) of population density per $100 \mathrm{~cm}^{3}$ of rhizosphere soil collected from Miscanthus $\times$ giganteus and switchgrass plots. Population densities are pooled data showing range of surveyed nematode densities per $100 \mathrm{~cm}^{3}$ rhizosphere soil collected from Miscanthus $\times$ giganteus and switchgrass plots. nematodes capable of causing significant biomass reductions on monocotyledonous hosts. The results show variability in the population levels of plant-parasitic nematodes among sampling sites (Table 1). At most locations, data on the frequency of occurrence and population densities for the different groups were found above damage threshold levels established for monocotyledon hosts by the University of Illinois (Table 2) $(2,3)$.

This survey indicates that Helicotylenchus, Xiphinema, and Pratylenchus spp. are widespread, have a high prominence value, and are above the damage thresholds established for some monocotyledon hosts in approximately one-third of the samples tested (Figs. 2 and 3; Table 2). Helicotylenchus spp. were common and recorded at 90.5 and $91.6 \%$ in Miscanthus $\times$ giganteus and switchgrass samples, respectively. The high abundance and frequency indicate that species of this genus most likely have a host-parasite relationship with Miscanthus $\times$ giganteus and switchgrass. Xiphinema spp. were found in 83.8 and $75.0 \%$ of the Miscanthus $\times$ giganteus and switchgrass samples, respectively. The highest number recorded in the survey $\left(1,200\right.$ per $100 \mathrm{~cm}^{3}$ of soil) was observed at the Urbana, IL, sampling site and suggests that Xiphinema spp. may have a host-parasite relationship with Miscanthus $\times$ giganteus and switchgrass. Pratylenchus spp. were found 91.9 and $83.3 \%$ of the Miscanthus $\times$ giganteus and switchgrass samples, respectively. The highest population densities of Pratylenchus spp. were recorded from three of the sites in Illinois: Dixon Springs $\left(184\right.$ per $100 \mathrm{~cm}^{3}$ of soil), Urbana (206 per $100 \mathrm{~cm}^{3}$ of soil), and Havana (420 per $100 \mathrm{~cm}^{3}$ of soil). Population levels of $L$. breviannulatus were high (33 per $100 \mathrm{~cm}^{3}$ of soil) at the Havana, IL sampling site and caused visible stunting of lateral roots and destruction of the fibrous root system (28).

Hoplolaimus, Heterodera, Tylenchorhynchus, Criconemella, Paratrichodorus, and Hemicriconemoides spp. were identified at several sampling sites (Table 1). When these species were present, they had relatively high population numbers but were not ubiquitous. Paratylenchus spp. were recorded in 43.2 and $33.3 \%$ of sites sampled in Miscanthus $\times$ giganteus and switchgrass samples, respectively. This genera of nematode is frequently identified in association with several plant species, though their potential for direct damage to crops is not well known.

Concomitant infestations by Pratylenchus, Xiphinema, Longidorus, and Hoplolaimus spp. were observed, and $10 \%$ of the sampling sites were co-infected by more than one of these nematodes. For example, Longidorus spp. were detected concomitantly with Xiphinema, Pratylenchus, and Hoplolaimus spp. at the Havana, IL sampling site. Population levels in most of the concomitantly infested fields were above the established damage threshold levels established for a monocotyledon host (Table 2).

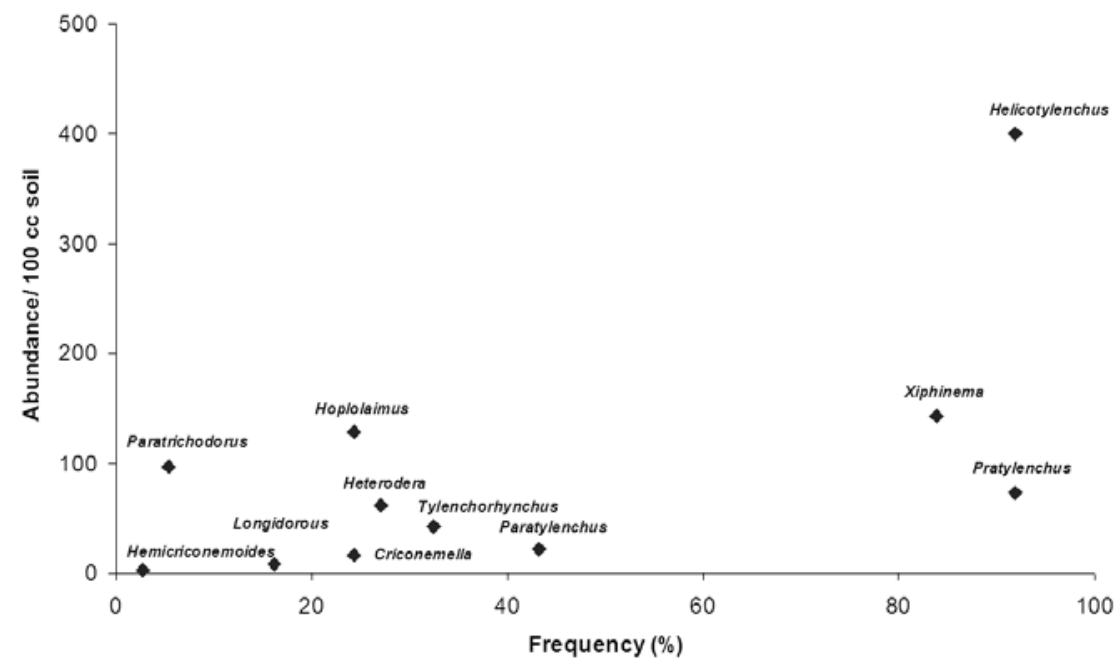

Fig. 2. Frequency (\%) and abundance of the major nematode species from rhizosphere soil of Miscanthus $\times$ giganteus at 12 field sites in the midwestern and southeastern United States during 2008 and 2009 soil surveys. 
Soil types of sampling fields varied in texture with sandy loam, silty loam, silty clay loam, clay loam, loam, and loamy sand (Table 1). Soil $\mathrm{pH}$ ranged from 5.6 to 8.8. There was no consistent trend in numbers of individual or combined nematode population densities in relation to soil type and soil $\mathrm{pH}$ except for $L$. breviannulatus. The occurrence of this nematode seems to be localized and restricted to highly sandy soils in Havana, IL (Table 1).

Our survey results from 2008 and 2009 sampling season identified, to the species level, 20 and 24 plant-parasitic nematodes associated with Miscanthus $\times$ giganteus and switchgrass, respectively (Tables 3 and 4). The species that are potentially damaging to these biofuel crops include six species of Pratylenchus ( $P$. penetrans, $P$. hexincisus, $P$. scribneri, $P$. brachyurus, $P$. crenatus, and $P$. neglectus), two species of Xiphinema ( $X$. rivesi and $X$. americanum), three species of Helicotylenchus (Helicotylenchus pseudorobustus, $H$. platyurus, and $H$. digonicus) two species of Longidorus ( $L$. breviannulatus and L. americanum), Hoplolaimus galeatus, Heterodera glycines, and two unidentified populations of Heterodera.

\section{Discussion}

The objective of this study was to determine population densities and the extent of infestation by plant-parasitic nematodes on Miscanthus $\times$ giganteus and switchgrass in experimental plots in Illinois, Iowa, South Dakota, Kentucky, Tennessee, and Georgia of the United States. Our survey results demonstrate the widespread occurrence of plant-parasitic nematodes in more than $90 \%$ of Miscanthus $\times$ giganteus and switchgrass plots sampled during 2008 and 2009. Comparison of these results with other surveys on switchgrass indicates the presence of a similar composition of plant-parasitic nematodes of reported significance $(6,14)$. All sites sampled had at least two nematode species that have been reported to reduce biomass in most monocotyledons hosts $(2,3)$.

The damage potential of any plant-parasitic nematode species to a given plant species depends on the host plant susceptibility, population density, and other ecological factors such as such as soil texture, temperature, moisture, organic matter, $\mathrm{pH}$, and associated soil microorganisms $(33,38)$. Pratylenchus, Xiphinema, Longidorus, Hoplolaimus, Tylenchorhynchus, Helicotylenchus, and Criconemella spp. have been reported to cause direct and indirect damage to several monocotyledons such as corn, bent grass, switchgrass, and turf grasses $(6,22,28,33,34,49)$. These groups of nematodes are probably of the most concern to Miscanthus $\times$ giganteus and switchgrass producers, because they have shown the most damage elsewhere. Though population levels of these nematodes that damage Miscanthus $\times$ giganteus and switchgrass are not known, the nematode densities encountered in our survey may represent the potential for disease in biofuel production based on the damage threshold densities reported for nematodes on other monocotyledon hosts such as corn $(2,3)$.

Genus Helicotylenchus was the most frequently identified nematode in our survey. High population densities of this genus can cause root damage and establish entry points for other soilborne pathogens (55). Some studies have suggested high population densities (>300 nematodes per $100 \mathrm{~cm}^{3}$ of soil) of Helicotylenchus spp. are necessary to cause economic damage to hosts $(2,3)$. However, a report from Iowa suggests that Helicotylenchus pseudorobustus may cause damage to corn and soybeans when population densities are 100 nematodes per $100 \mathrm{~cm}^{3}$ of soil (40). H. pseudorobustus was the primary species found during this survey. It was identified at most of the sampling sites on both Miscanthus $\times g i$ ganteus and switchgrass, and it has been associated with a wide range of plants, including prairie grasses, legumes, and corn $(12,31,41,50,55)$. Damage attributed to $H$. pseudorobustus has been reported in native prairie grasses, turf grasses $(8,52)$, and soybean

Table 3. Plant-parasitic nematodes species identified from the rhizosphere of 35 Miscanthus $\times$ giganteus plots at 12 field sites in the midwestern and southeastern United States during 2008 and 2009 rhizosphere soil surveys

\begin{tabular}{|c|c|c|c|c|}
\hline \multirow[b]{2}{*}{ Nematode } & \multicolumn{4}{|c|}{ Sample sites (no. of plots surveyed) } \\
\hline & IL (29) & IA (2) & KY (2) & GA (2) \\
\hline \multicolumn{5}{|l|}{ Dorylaimida } \\
\hline Xiphinema americanum & + & - & - & + \\
\hline$X$. rivesi & + & - & - & - \\
\hline Xiphinema spp. & - & - & - & - \\
\hline Longidorus breviannulatus & + & - & - & - \\
\hline Longidorus sp. & - & - & - & + \\
\hline \multicolumn{5}{|l|}{ Triplonchida } \\
\hline Paratrichodorus sp. & + & - & - & - \\
\hline \multicolumn{5}{|l|}{ Tylenchida } \\
\hline Pratylenchus penetrans & + & - & - & - \\
\hline P. hexincisus & + & - & + & + \\
\hline P. scribneri & + & + & + & + \\
\hline P. crenatus & + & + & - & - \\
\hline Hoplolaimus galeatus & + & + & + & - \\
\hline Heterodera glycines & + & + & + & _- \\
\hline Helicotylenchus pseudorobustus & + & + & - & - \\
\hline H. digonicus & + & - & + & - \\
\hline H. platyurus & - & - & - & - \\
\hline Helicotylenchus spp. & + & - & - & + \\
\hline Tylenchorhynchus agri & - & - & - & - \\
\hline Tylenchorhynchus sp. & + & - & + & - \\
\hline Criconemella spp. & + & - & - & - \\
\hline Paratylenchus sp. & + & - & - & - \\
\hline
\end{tabular}

a $\mathrm{IL}=$ Illinois, $\mathrm{IA}=$ Iowa, $\mathrm{KY}=$ Kentucky, and GA = Georgia; + indicates positive detection and - indicates negative detection.

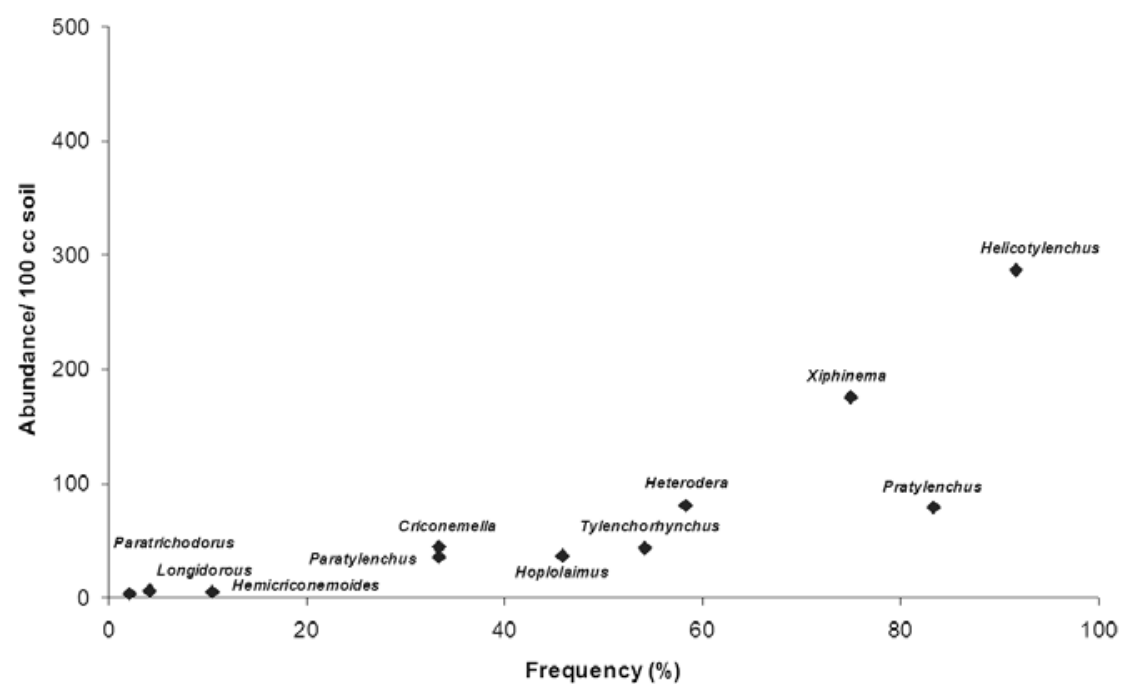

Fig. 3. Frequency (\%) and abundance of the major nematode species from rhizosphere soil of switchgrass plots at 17 field sites in the midwestern and southeastern United States during 2008 and 2009 soil surveys. 
(31). Accurate estimates of the damage threshold of $H$. pseudorobustus are needed. Populations counted in this survey exceeded the aforementioned thresholds in both Miscanthus $\times$ giganteus and switchgrass plots. Further studies are necessary to determine the economic importance of this species to Miscanthus $\times$ giganteus and switchgrass.

Our survey data showed the presence of two species of Xiphinema: $X$. americanum and $X$. rivesi. The highest population density $\left(1,200\right.$ per $100 \mathrm{~cm}^{3}$ of soil) was recorded for $X$. americanum at the plots near Urbana, IL. The Xiphinema nematodes are commonly found in North America and have a wide host range that includes grasses, soybean, and perennial orchards $(12,41,43,54)$. They are ectoparasites and known vectors of certain viruses (40). The impact of Xiphinema spp. on Miscanthus $\times$ giganteus and switchgrass has not been established. Future work is necessary to determine their importance to Miscanthus $\times$ giganteus and switchgrass.

Six species of Pratylenchus (P. penetrans, $P$. hexincisus, $P$. scribneri, $P$. brachyurus, $P$. crenatus, and $P$. neglectus) were identified in our survey. The root-lesion nematodes $P$. scribneri, $P$. penetrans, and $P$. crenatus were quite common and frequently detected at several Miscanthus $\times$ giganteus and switchgrass sampling sites. These species have been reported as pests of several plant species such as grasses, cereals, and legumes and, thus, they could be considered potential pests of Miscanthus $\times$ giganteus and switchgrass $(6,10,12,13,40)$. When compared with damage thresholds for monocotyledon hosts, the results of this study suggest that Pratylenchus species will be a potential problem for Miscanthus $\times$ giganteus and switchgrass production.

In our survey, L. breviannulatus was recovered from the Havana, IL sampling site at high population densities, and they appeared to be stunting the lateral roots and destroying the fibrous roots of Miscanthus $\times$ giganteus. These observations indicate that this nematode may have the potential to substantially reduce biomass production. First described from Iowa and associated with corn (39), this species has been found in North America in association with several plant hosts such as corn and several grass species $(29,30,34,48)$. Malek et al. (30) considered L. breviannulatus to be the most devastating nematode attacking corn. The relationship between nematode density and Miscanthus $\times$ giganteus and switchgrass yield remains unclear and must be studied further.

Detections of different species from the genera Hoplolaimus, Heterodera, Tylenchorhynchus, Criconemella, Paratrichodorus, and Hemicriconemoides revealed low frequencies in the sampled Miscanthus $\times$ giganteus and switchgrass plots. It is probable that a host-parasite relationship exists, although there does not seem to be a strong parasitic relationship with Miscanthus $\times$ giganteus and switchgrass. However, it would be prudent to monitor these fields closely to determine whether a nematode population increase occurs, which could indicate a possible host-parasite relationship.

To our knowledge, this is the first detailed report and description of these plant-parasitic nematodes associated with Miscanthus $\times$ giganteus. Further studies have been initiated to determine the host suitability and damage thresholds of Pratylenchus and Longidorus spp. to Miscanthus $\times$ giganteus and switchgrass under greenhouse and field conditions. Future work will focus on host suitability, damage thresholds, and population dynamics of the most prevalent nematodes associated with Miscanthus $\times$ giganteus and switchgrass. This information will be used in estimating the impact of nematodes on the yield potential of the Miscanthus $\times$ giganteus and switchgrass biomass.

\section{Acknowledgments}

We thank A. Colgrove for technical assistance. This research was supported by the Energy Biosciences Institute (EBI) and the University of Illinois Agricultural Experiment Station.

\section{Literature Cited}

1. Al-Banna, L., Willamson, V. M., and Gardner, S. L. 1997. Phylogenetic analysis of nematodes of the genus Pratylenchus using nuclear 26S rDNA. Mol. Phylogenet. Evol. 7:94-102.

2. Anonymous 1. 1997. The ectoparasitic nematodes of Illinois. Report on Plant Diseases, Department of Crop Sciences, University of Illinois. RPD 1106:1-8.

3. Anonymous 2. 2000. Nematode parasites of turf grass. Report on Plant Diseases, Department of Crop Sciences, University of Illinois. RPD 1108:1-8.

4. Beale, C. V., and Long, S. P. 1997. Seasonal dynamics of nutrient accumu-

Table 4. Plant-parasitic nematodes species identified from the rhizosphere of 48 switchgrass plots at 17 field sites in the midwestern and southeastern United States during 2008 and 2009 rhizosphere soil surveys

\begin{tabular}{|c|c|c|c|c|c|c|}
\hline \multirow[b]{2}{*}{ Nematode } & \multicolumn{6}{|c|}{ Sample sites (no. of plots surveyed) ${ }^{a}$} \\
\hline & IL (29) & IA (2) & SD (11) & KY (2) & TN (2) & GA (2) \\
\hline \multicolumn{7}{|l|}{ Dorylaimida } \\
\hline Xiphinema americanum & + & + & - & + & - & + \\
\hline$X$. rivesi & + & - & - & - & _- & - \\
\hline Xiphinema spp. & - & - & - & - & + & - \\
\hline Longidorus breviannulatus & + & _- & _- & _- & - & - \\
\hline Longidorus sp. & - & - & - & - & - & + \\
\hline \multicolumn{7}{|l|}{ Triplonchida } \\
\hline Paratrichodorus sp. & + & - & - & - & + & + \\
\hline \multicolumn{7}{|l|}{ Tylenchida } \\
\hline Pratylenchus penetrans & + & - & + & - & - & - \\
\hline P. hexincisus & + & - & - & + & - & + \\
\hline P. scribneri & + & + & - & + & + & + \\
\hline P. brachyurus & - & - & + & - & - & - \\
\hline P. crenatus & + & + & - & - & - & - \\
\hline P. neglectus & + & - & - & - & - & - \\
\hline Hoplolaimus galeatus & + & + & - & + & + & - \\
\hline Heterodera glycines & + & + & - & + & + & _- \\
\hline Heterodera sp. & + & - & - & - & - & - \\
\hline Helicotylenchus pseudorobustus & + & + & + & - & + & - \\
\hline H. digonicus & + & - & - & + & - & - \\
\hline H. platyurus & - & - & + & - & - & - \\
\hline Helicotylenchus spp. & + & - & - & - & - & + \\
\hline Tylenchorhynchus nudus & - & - & + & - & - & - \\
\hline T. agri & + & - & - & _- & _- & _- \\
\hline Tylenchorhynchus sp. & + & - & - & + & - & - \\
\hline Criconemella spp. & + & + & - & + & + & _- \\
\hline Paratylenchus sp. & + & - & - & - & - & - \\
\hline
\end{tabular}

${ }^{\mathrm{a}} \mathrm{IL}=$ Illinois, IA = Iowa, SD = South Dakota, $\mathrm{KY}=$ Kentucky, TN = Tennessee, and GA = Georgia; + indicates positive detection and - indicates negative detection. 
lation and partitioning in the perennial C4-grasses Miscanthus $\times$ giganteus and Spartina cynosuroides. Biomass Bioenergy 12:419-428.

5. Carta, L. K., Skantar, A. M., and Handoo Z. A. 2001. Molecular, morphological and thermal characters of 19 Pratylenchus spp. and relatives using the D3 segment of the nuclear LSU rRNA gene. Nematropica 31:193-207.

6. Cassida, K. A., Kirkpatrick, T. L., Robbins, R. T., Muir, J. P., Venuto, B. C., and Hussey, M. A. 2005. Plant-parasitic nematodes associated with switchgrass (Panicum virgatum L.) grown for biofuels in the south central United States. Nematropica 35:1-10.

7. Castillo, P., and Vovlas, N. 2007. Pratylenchus, Nematoda, Pratylenchidae: Diagnosis, biology, pathogenicity and management. Nematology Monograph and Perspectives.

8. Chastagner, G. A., and McElroy, F. D. 1984. Distribution of plant parasitic nematodes in putting green turfgrass in Washington. Plant Dis. 68:151-153.

9. Chen, Q., Hopper, D. J., Loof, P. A. A., and Xu, J. 1997. A revised polytomous key for the identification of the genus Longidorus Micoletzky 1992 (Nematoda: Dorylaimoidea). Fundam. Appl. Nematol. 20:15-28.

10. De Waele, D., McDonald, A. H., Jordan, E. M., Orion, D., Van Den Berg, E., and Loots, G. C. 1998. Plant-parasitic nematodes associated with maize and pearl millet in Namibia. Afr. Plant Prot. 4:113-117.

11. Dinardo-Miranda, L. L., and Fracasso, J. V. 2009. Spatial distribution of plant-parasitic nematodes in sugarcane fields. Sci. Agric. 66:188-194.

12. Ferris, V. R., and Bernard, R. L. 1985. Plant parasitic nematodes associated with soybeans in Illinois. Plant Dis. Rep. 42:798-801.

13. Ferris, V. R., Ferris, J. M., Bernard, R. L., and Probst, A. H. 1971. Community structure of plant parasitic nematodes related to soil types in Illinois and Indiana soybean fields. J. Nematol. 3:399-408.

14. Firoza, K., and Maqbool, M. A. 1994. A diagnostic compendium of the genus Helicotylenchus Steiner, 1945 (Nematoda: Hoplolaimidae). Pak. J. Nematol. 12:11-50.

15. Forer, L. B. 1977. Longidorus breviannulatus associated with a decline of bentgrass in Pennsylvania. Plant Dis. Rep. 61:8.

16. Frederick, J. J., and Tarjan, A. C. 1989. A compendium of the genus Pratylenchus Filipjev, 1936 (Nemata: Pratylenchidae). Rev. Nématol. 12:243256.

17. Handoo, Z. A. 2000. A Key and Diagnostic Compendium to the Species of the Genus Tylenchorhynchus Cobb, 1913 (Nematoda: Belonolaimidae). J. Nematol. 32:20-34.

18. Handoo, Z. A., and Golden, A. M. 1989. A key and compendium to the species of Pratylenchus (lesion nematodes). J. Nematol. 21:202-218.

19. Heaton, E. A., Flavell, R. B., Mascia, P. N., Thomas, S. R., Dohleman, F. G., and Long, S. P. 2008. Herbaceous energy crop development: Recent progress and future prospects. Curr. Opin. Biotechnol. 19:202-209.

20. Hooper, J. D. 1985. Extraction of free-living stages from soil. Pages 5-30 in: Laboratory Methods for Work with Plant and Soil Nematodes: Reference Book 402. J. F. Southey, ed. Ministry of Agriculture, Fisheries and Food, United Kingdom.

21. Hooper, J. D. 1985. Handling, fixing, staining and mounting nematodes. Pages 59-80 in: Laboratory Methods for Work with Plant and Soil Nematodes: Reference Book 402. J. F. Southey, ed. Ministry of Agriculture, Fisheries and Food, United Kingdom.

22. Ingham, R. E., and Detling, J. K. 1984. Plant-herbivore interactions in a North American mixed-grass prairie-III. Soil nematode populations and root biomass on Cynomys ludovicianus colonies and adjacent uncolonized areas. Oecologia 63:307-313.

23. Johnson, W. 1970. Pathogenicity and interaction of three nematode species on six Bermuda grasses. J. Nematol. 2:36-41.

24. Jordan, K. S., and Mitkowski, N. A. 2006. Population dynamics of plantparasitic nematodes in golf course greens turf in Southern New England. Plant Dis. 90:501-505.

25. Kokalis-Burelle, N., Mahaffee, W. F., Rodriquez-Kabana, R., Kloepper, J. W, and Bowen, K. L. 2002. Effects of switchgrass (Panicum virgatum) rotations with peanut (Arachis hypogaea L.) on nematode populations and soil microflora. J. Nematol. 34:98-105.

26. Lamberti, F., Hockland, S., Agosttinelli, A., Moens, M., and Brown, D. J. F. 2004. The Xiphinema americanum group III: keys to species identification. Nematol. Mediterr. 32:53-56.

27. LaMondia, J. A. 1995. Response of perennial herbaceous ornamentals to Meloidogyne hapla. J. Nematol. (Suppl.) 27:645-648.

28. Luc, M., Sikora, R. A., and Bridge, J. 1990. Plant-Parasitic Nematodes in Subtropical and Tropical Agriculture. CAB International Institute of Parasitology, Wallingford, UK.
29. MacGuidwin, A. E. 1989. Abundance and vertical distribution of Longidorus breviannulatus associated with corn and potato. J. Nematol. 21:404408.

30. Malek, R. B., Norton, D. C., Jacobsen, B. J., and Acosta, N. 1980. A new corn disease caused by Longidorus breviannulatus in the Midwest. Plant Dis. 64:1110-1113.

31. McGawley, E. C., and Chapman, R. A. 1983. Reproduction of Criconemoides simile, Helicotylenchus pseudorobustus, and Paratylenchus projectus on soybean. J. Nematol. 15:87-91.

32. McLaughlin, S., Bouton, J., Bransby, D., Conger, B., Ocumpaugh, W., Parrish, D., Taliaferro, C., Vogel, K., and Wullschleger, S. 1999. Developing switchgrass as a bioenergy crop. Pages 282-299 in: Perspectives on New Crops and New Uses. J. Janick, ed. ASHS Press, Alexandria, VA.

33. McSorley, R., and Dickson, D. W. 1989. Effects and dynamics of a nematode community on maize. J. Nematol. 21:462-471.

34. Mekete, T., Grey, M., and Niblack, T. 2009. Distribution, morphological description, and molecular characterization of Xiphinema and Longidorus spp. associated with plants (Miscanthus spp. and Panicum virgatum) used for biofuels. Glob. Change Biol. 1:257-266.

35. Minagawa, N. 1982. An additional new species of genus Nothocriconema from Mt. Aso (Tylenchida: Criconematidae). Jpn. J. Nematol. 11:24-27.

36. Minagawa, N. 1986. Description of Verutus mesoangustus n. sp. (Tylenchida: Heteroderidae) from Japan. Appl. Entomol. Zool. 21:277-282.

37. Mizukubo, T. 1989. Description of Radopholus sanoi n. sp. from Kyushu, Japan. Jpn. J. Nematol. 8:39-44.

38. Norton, D. C. 1989. Abiotic soil factors and plant-parasitic nematode communities. J. Nematol. 21:299-307.

39. Norton, D. C., and Hoffmann, J. K. 1975. Longidorus breviannulatus n. sp. (Nematoda: Longidoridae) associated with stunted corn in Iowa. J. Nematol. 7:168-171.

40. Norton, D. C., and Nyvall, R. F. 1999. Nematodes that attack corn in Iowa. Pages 1-8 in: Univ. Iowa Ext. Bull.

41. Norton, D. C., and Schmitt, D. P. 1978. Community analyses of plant-parasitic nematodes in the Kalsow Prairie, Iowa. J. Nematol. 10:171-176.

42. Perry, V. G., and Smart, G. C. 1970 . Nematode problems of turfgrasses in Florida and their control. Proc. Fla. State Hortic. Soc. 83:489-492.

43. Robbins, R. T. 1993. Distribution of Xiphinema americanum and related species in North America. J. Nematol. 25:344-348.

44. Roman, J., and Hirschmann, H. 1969. Morphology and morphometrics of six species of Pratylenchus. J. Nematol. 1:363-386.

45. Sanderson, M. A., and Adler, P. R. 2008. Perennial forages as second generation bioenergy crops. Int. J. Mol. Sci. 9:768-788.

46. Sanderson, M. A., and Wolf, D. D. 1996. Morphological development of switchgrass in diverse environments. Agron. J. 88:908-915.

47. Sikora, R. A., Taylor, D. P., Malek, R. B., and Edwards, D. I. 1972. Interaction of Meloidogyne naasi, Pratylenchus penetrans and Tylenchorhynchus agri on creeping bentgrass. J. Nematol. 4:162-165.

48. Simard, L., Bélair, G., and Miller, S. 2009. First report of Longidorus breviannulatus associated with damage on creeping bentgrass golf greens in Québec, Canada. Plant Dis. 93:846.

49. Stanton, N. L. 1988. The underground in grasslands. Annu. Rev. Ecol. Syst 19:573-589.

50. Taylor, D. P. 1961. Biology and host-parasite relationships of the spiral nematode Helicotylenchus microlobus. Proc. Helminthol. Soc. Wash. 28:6066.

51. Todd, T. C., Powers, T. O., and Mullin, P. G. 2006. Sentinel nematodes of land-use change and restoration in tallgrass prairie. J. Nematol. 38:20-27.

52. Todd, T. C., and Tisserat, N. A. 1990. Occurrence, spatial distribution, and pathogenicity of some phytoparasitic nematodes on creeping bentgrass putting greens in Kansas. Plant Dis. 74:660-663.

53. Turner, S. J., and Rowe, J. A. 2006. Cyst nematodes. Pages 91-120 in: Plant Nematology. R. N. Perry and M. Moens, eds. CABI Publishing, Wallingford, UK

54. Walters, S. A., Bond, J. P., Russell, J. B., Taylor, B. H., and Handoo, Z. A. 2008. Incidence and influence of plant-parasitic nematodes in Southern Illinois peach orchards. Nematropica 38:63-74.

55. Yeates, G. W. 1984. Helicotylenchus pseudorobustus (Nematoda: Tylenchida) population changes under pasture during thirty-six months. Pedobiologia 27:221-228.

56. Yu, Q., Potter, J. W., and Gilby, G. 1998. Plant parasitic nematodes associated with turf grass in golf courses in southern Ontario. Can. J. Plant Pathol. 20:304-307. 